Article

\title{
Biosorption of Rare Earth Elements by Different Microorganisms in Acidic Solutions
}

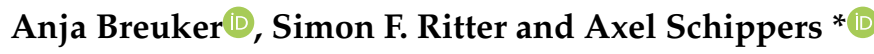 \\ Federal Institute for Geosciences and Natural Resources (BGR), Stilleweg 2, 30655 Hannover, Germany; \\ anja.breuker@online.de (A.B.); sim.ritter@gmail.com (S.F.R.) \\ * Correspondence: axel.schippers@bgr.de
}

Received: 22 June 2020; Accepted: 12 July 2020; Published: 15 July 2020

\begin{abstract}
Acidic solutions from metal bioleaching processes usually contain mixtures of metals in different concentrations which need to be separated and concentrated in downstream processing. Aim of this study was to explore and compare biosorption of rare earth elements (REE) by different microorganisms in acidic solutions. Biosorption of REE by bacteria and fungi showed element selective biosorption. The gram-positive bacterium Bacillus subtilis showed a higher selectivity to ytterbium $(\mathrm{Yb})$ and lutetium $(\mathrm{Lu})$ than the gram-negative bacteria Leisingera methylohalidivorans and Phaeobacter inhibens. In contrast, the tested fungi (Catenulostroma chromoblastomyces, Pichia sp.) showed a preference for the middle rare earth elements. Algae exhibited a low biosorption performance. Additionally, for B. subtilis and one yeast (Pichia sp.), better results were achieved with living than dead biomass. This study compares for the first time biosorption of different microorganisms at standardized conditions at low $\mathrm{pH}$ und application related conditions.
\end{abstract}

Keywords: biosorption; rare earth elements; acidic solution; B. subtilis; Pichia sp.

\section{Introduction}

The ability of microbial cells to sequester solutes selectively from aquatic solutions, via non-metabolically mediated pathways, has been termed biosorption [1]. With other words, biosorption can be defined as the removal of substances from solution by biological material $[2,3]$. Biosorption can be performed in a wide range of $\mathrm{pH}$ values 3-9 [4]. Nevertheless, the major part of the studies under acidic conditions were carried out for one or two elements in solution and mild acidic conditions $(\mathrm{pH}>3)[5,6]$. The $\mathrm{pH}$ is possibly the most important physico-chemical parameter for biosorption and competition between cations and protons for binding sites means that biosorption of metals like $\mathrm{Cu}, \mathrm{Cd}, \mathrm{Ni}, \mathrm{Co}$ and $\mathrm{Zn}$ is often reduced at low $\mathrm{pH}$ values [3].

Bioleaching usually takes place in acidic solutions with low $\mathrm{pH}(<2-3)$. These solutions contain mixtures of heavy metals in different concentrations which need to be separated and concentrated in downstream processing. Here biosorption might be an option.

Due to high economy delivery risks, special attention has been paid to rare earth elements (REE) and their recovery from primary and secondary resources over the last years [7].

Biosorption of REE at low $\mathrm{pH}$ has been studied in some cases [8-16]. Comparing these studies, it is obvious that the conditions under which biosorption experiments took place are often not comparable due to different sorbent/metal ratios even if isotherm studies with increasing metal concentrations were carried out. Therefore, the results in the literature for various microorganisms often rather reflect the experimental conditions than comparable differences between the microorganisms. Aim of this study was to elucidate biosorption of REEs with different microorganisms at comparable acidic conditions. Biosorption experiments were carried out with a mixed solution containing eight REEs (lanthanum, cerium, neodymium, gadolinium, dysprosium, erbium, ytterbium and lutetium). 
Additionally, to test the applicability, an experiment with a gadolinium-containing wastewater was performed.

\section{Material and Methods}

\subsection{Microorganisms and Cultivation Conditions}

Different Bacteria and Eukarya were selected and grown at specific cultivation conditions (Table 1) to obtain enough biomass for biosorption experiments. The organisms were mainly selected because REE biosorption was described for them in the literature, partly at low $\mathrm{pH}$.

Two eukaryotic microorganisms from the BGR culture collection were selected because of their high biosorption performance at neutral $\mathrm{pH}$ studied in previous work.

Their phylogeny was investigated as described below.

The composition of the media is described as follows:

FP medium: meat peptone (Roth \#2366.1) $8 \mathrm{~g} / \mathrm{L}$, casein peptone (Roth, \#8986.1) $2 \mathrm{~g} / \mathrm{L}$, yeast extract $0.5 \mathrm{~g} / \mathrm{L}, \mathrm{NaCl} 2 \mathrm{~g} / \mathrm{L}$ adjusted to $\mathrm{pH} 7.0$, after autoclaving $0.2 \mu \mathrm{m}$ filtered glucose $(400 \mathrm{~g} / \mathrm{L})$ was added to a final concentration of $4 \mathrm{~g} / \mathrm{L}$.

NB medium: Difco ${ }^{\mathrm{TM}}$ Nutrient Broth.

Malt medium: biomalt $40 \mathrm{~g} / \mathrm{L}$, casein peptone $5 \mathrm{~g} / \mathrm{L},\left(\mathrm{NH}_{4}\right)_{2} \mathrm{HPO}_{4} 1 \mathrm{~g} / \mathrm{L}$, adjusted to $\mathrm{pH} 6$.

Cyanidium medium: $\left(\mathrm{NH}_{4}\right)_{2} \mathrm{SO}_{4} 1 \mathrm{~g} / \mathrm{L} ; \mathrm{K}_{2} \mathrm{HPO}_{4} 0.02 \mathrm{~g} / \mathrm{L} ; \mathrm{MgSO}_{4} \cdot 7 \mathrm{H}_{2} \mathrm{O} 0.02 \mathrm{~g} / \mathrm{L}$; soil extract $30 \mathrm{~mL} / \mathrm{L}$, adjusted to $\mathrm{pH} 4.0$.

Preparation of soil extract for cyanidium medium: Fill a 6-L flask one third with garden or leaf soil of medium, but not too great humus content which does not contain fertilizers or plant protective agents. Success of soil extract depends on selection of suitable soils. Those with high clay content are usually less satisfactory. Add de-ionized water until it stands $5 \mathrm{~cm}$ above the soil and sterilize by heating in a steamer for one hour twice in a $24 \mathrm{~h}$ interval. Separate the decanted extract from particles by centrifugation. Fill into small containers of stock solution each of a size appropriate to making a batch of media, autoclave for $20 \mathrm{~min}$ at $121^{\circ} \mathrm{C}$ and store in the refrigerator. (http://sagdb.uni-goettingen.de/culture_media/17\%20Cyanidium\%20Medium.pdf)

WC medium: Prepared as described by Guillard and Lorenzen 1972 [22].

$2 \times$ Allens medium (1:1diluted): $\left(\mathrm{NH}_{4}\right)_{2} \mathrm{SO}_{4} 2.62 \mathrm{~g} / \mathrm{L} ; \mathrm{KH}_{2} \mathrm{PO}_{4} 0.54 \mathrm{~g} / \mathrm{L} ; \mathrm{MgSO} 4 \cdot 7 \mathrm{H} 2 \mathrm{O} 0.5 \mathrm{~g} / \mathrm{L} ; \mathrm{Ca}$ $\mathrm{Cl}_{2} \cdot 2 \mathrm{H}_{2} \mathrm{O} 0.14 \mathrm{~g} / \mathrm{L} ; \mathrm{FeCl}_{3} \cdot 6 \mathrm{H}_{2} \mathrm{O} 0.016 \mathrm{~g} / \mathrm{L}$

Aron's A6 trace element solution for Allens medium: $\mathrm{MnCl}_{2} \cdot 4 \mathrm{H}_{2} \mathrm{O} 1.8 \mathrm{~g} / \mathrm{L} ; \mathrm{ZnCl}_{2} 0.105 \mathrm{~g} / \mathrm{L}$; $\mathrm{Na}_{2} \mathrm{MoO}_{4} \cdot 2 \mathrm{H}_{2} \mathrm{O} 0.39 \mathrm{~g} / \mathrm{L} ; \mathrm{CoCl}_{2} \cdot 6 \mathrm{H}_{2} \mathrm{O} 0.05 \mathrm{~g} / \mathrm{L} ; \mathrm{CuCl}_{2} \cdot 2 \mathrm{H}_{2} \mathrm{O} 0.06452 \mathrm{~g} / \mathrm{L} ;$ add $2 \%$ to medium. 
Table 1. Cultivation conditions for microorganisms used for biosorption experiments.

\begin{tabular}{|c|c|c|c|c|c|c|c|}
\hline Organism & Taxonomy & Medium & Tempe-Rature & Type of Flasks & $\begin{array}{c}\text { rpm on } \\
\text { the Shaker }\end{array}$ & Incuba-Tion Time (Days) & Reference \\
\hline $\begin{array}{l}\text { Leisingeria methylo-halidivorans } \\
\text { DSM } 14336\end{array}$ & $\begin{array}{l}\text { Bacteria (gram-negative, } \\
\text { Roseobacter clade }\end{array}$ & $\begin{array}{l}\text { Marine Broth medium } \\
\text { (Difco, MB2216) }\end{array}$ & $20^{\circ} \mathrm{C}$ & Bullying flasks & 80 & 2 & [17] \\
\hline Phaeobacter inhibens DSM 17395 & $\begin{array}{l}\text { Bacteria (gram-negative, } \\
\text { Roseobacter clade }\end{array}$ & $\begin{array}{l}\text { Marine Broth medium } \\
\text { (Difco, MB2216) }\end{array}$ & $20^{\circ} \mathrm{C}$ & Bullying flasks & 80 & 2 & [17] \\
\hline Bacillius subtilis ATCC 7003 & Bacteria (gram-positive) & FP medium & $30^{\circ} \mathrm{C}$ & Erlen-meyer flasks & 120 & $2-4$ & [18-20] \\
\hline Pezicomy-cotina sp. & Eukarya (fungus) & FP medium & $30^{\circ} \mathrm{C}$ & Erlen-meyer flasks & 120 & $\sim 10$ & BGR culture M8 \\
\hline Fusarium sp. & Eukarya (fungus) & malt medium & $30^{\circ} \mathrm{C}$ & Erlen-meyer flasks & 120 & $2-4$ & BGR culture \\
\hline $\begin{array}{c}\text { Catenulostro-ma } \\
\text { chromo-blastomyces CBS } 597.97\end{array}$ & Eukarya (fungus) & malt medium & $30^{\circ} \mathrm{C}$ & Erlen-meyer flasks & 120 & $2-4$ & [16] \\
\hline Pichia sp. & Eukarya (fungus, yeast) & malt medium & $30^{\circ} \mathrm{C}$ & Erlen-meyer flasks & 120 & $2-4$ & BGR culture \\
\hline Pichia naganishii [MB\#320511] & Eukarya (fungus, yeast) & NB medium & $30^{\circ} \mathrm{C}$, & Erlen-meyer flasks & 120 & $2-4$ & BGR culture \\
\hline Saccharo-myces cerevisiae & Eukarya (fungus, yeast) & Sabouraud medium & $30^{\circ} \mathrm{C}$ & Erlen-meyer flasks & 120 & $2-4$ & [21] \\
\hline Galderia sulphuraria & Eukarya, Rhodo-phyta (algae) & $\begin{array}{l}\text { Cyanidium medium and } 2 \times \\
\text { Allens medium }\end{array}$ & $\begin{array}{c}20^{\circ} \mathrm{C}, 30^{\circ} \mathrm{C} \\
\text { sunlight and dark }\end{array}$ & $\begin{array}{l}\text { Baffled shake } \\
\text { flasks }\end{array}$ & 200 & $\sim 14$ & [15] \\
\hline Messastrum gracilis & Eukarya, Chloro-phyta (algae) & WC medium & $\begin{array}{c}20^{\circ} \mathrm{C}, 30^{\circ} \mathrm{C}, \\
\text { sunlight and dark }\end{array}$ & $\begin{array}{l}\text { Baffled shake } \\
\text { flasks }\end{array}$ & 200 & $\sim 14$ & [12] \\
\hline
\end{tabular}




\subsection{Biosorption Experiments with Suspended Biomass}

Cell biomass (BM) was harvested by centrifugation with the High Speed Centrifuge Sorvall RC6 plus (7000 g, 10-20 min; Thermo Electron, Langenselbold, Germany) of grown cultures, and washed twice with autoclaved Milli- $\mathrm{Q}^{\circledR}$ water at $\mathrm{pH} 2.5(\mathrm{HCl})$. BM dry weight was measured with the HC 103 device (Mettler Toledo, Albstadt, Germany). BM was suspended in $\mathrm{pH}$ adjusted and autoclaved Milli- $Q^{\circledR}$ water in measuring pistons at room temperature.

REE solutions ( $\mathrm{pH} 2.5, \mathrm{HCl}$ ) were manually prepared from chloride salts of REEs ( $\mathrm{La}, \mathrm{Ce}, \mathrm{Nd}, \mathrm{Gd}$, $\mathrm{Dy}, \mathrm{Er}, \mathrm{Yb}$ and $\mathrm{Lu}$ ) and added to BM to the required final concentrations (BM $5 \mathrm{~g} / \mathrm{L}, \mathrm{REEs} 15 \mu \mathrm{mol} / \mathrm{L}$ each). REE/zirconium/iron solutions for competition experiments were prepared in the same way with addition of iron $\left(\mathrm{FeCl}_{2}\right)$ and zirconium $\left(\mathrm{ZrOCl}_{2}\right)$ to a final concentration of $264 \mu \mathrm{mol} / \mathrm{L}$ and $16 \mu \mathrm{mol} / \mathrm{L}$, respectively. For tests with dead vs. living BM, the collected and centrifuged samples were autoclaved with a small amount of medium before experiments.

Experiments were done in duplicates for BM assays and controls (assay without BM) if not shown differently. REE concentrations were measured in samples of supernatants taken after different time intervals by inductively coupled plasma mass spectrometry (ICP-MS, Agilent 7700, Agilent Technologies, Waldbron, Germany) after centrifugation and filtration of samples ( $0.2 \mu \mathrm{m}$ nylon membrane). The $\mathrm{pH}$ was measured with the $\mathrm{pH}$-Meter 766 Calimatic device (Knick, Berlin, Germany, for medium) and the Five Easy Plus $\mathrm{pH} / \mathrm{mV}$ device (Mettler Toledo, Albstadt, Germany, for samples). Calculations were carried out by subtraction of REE concentrations $\left(c_{e}\right)$ from controls $\left(c_{i}\right)$ taken at the same time to exclude possible precipitations. Relative biosorption was calculated as follows: $\left(\left(c_{i}\right)-\left(c_{e}\right)\right) /\left(c_{i}\right)^{*} 100$. Amount of REE uptake was calculated by dividing the difference of the mean values between control and sample assays through biomass.

\subsection{Biosorption Conditions Experiments with Immobilized Biomass}

For immobilization and recovery rate experiments with selected microorganisms, highly purified agarose was diluted in water and autoclaved (solution A). After autoclaving, solution A was acidified to $\mathrm{pH} 2.5(\mathrm{HCl})$ and stored at $45^{\circ} \mathrm{C}$ to prevent solidification. Suspended biomass was adjusted to $\mathrm{pH}$ 2.5 after washing twice with acidified autoclaved Milli- $\mathrm{Q}^{\circledR}$ water $(\mathrm{pH} 2.5, \mathrm{HCl})$, for the control samples acidified autoclaved Milli- $\mathrm{Q}^{\circledR}$ water was used $(\mathrm{pH} 2.5, \mathrm{HCl})$, (solution B). Solutions A and B were mixed and quickly poured into four forms and let solidify to get platelets. These platelets were put into Erlenmeyer flasks which were previously filled with the REE solution. Solid/solution ratio was 1:4, the experiments were done in duplicate with four $2.5 \mathrm{~mL}$ platelets (total $10 \mathrm{~mL}$ with acidified Milli- $\mathrm{Q}^{\circledR}$ water or acidified biomass) and $40 \mathrm{~mL}$ acidified REE solution. After completion of the experiment, the platelets were mixed with $238 \mu \mathrm{L}$ concentrated nitric acid and incubated in a sandbathe over night at $80{ }^{\circ} \mathrm{C}$. The dry remnants were diluted in $2 \%$ nitric acid and analyzed by ICP-MS.

\subsection{Phylogenetic Analysis}

High-molecular-weight DNA of the yeast strain (BGR culture collection) and the fungus M8 (BGR culture collection) was extracted from pure cultures following the FastDNA Spin Kit for Soil (Bio101) protocol [23].

Cloning and sequencing of the ITS (internal transcribed spacer) sequence and the EF1 $\alpha$ (translation elongation factor $1 \alpha$ ) gene was done by the Microsynth AG (Switzerland). Sequences were manually edited and curated with BioEdit 7.2.5. Phylogenetic mapping was done at NCBI (www.ncbi.nlm. nih.gov) with BLAST [24]. Sequences were submitted to NCBI (accession numbers MN567305.1 and MN644911). For the fungus M8, similarly cloning and sequencing of the ITS sequence and $28 \mathrm{~s}$ Sequence was done by the Microsynth AG (Switzerland) and sequences were manually edited and curated with BioEdit 7.2.5 [25]. Phylogenetic mapping was done at NCBI (www.ncbi.nlm. nih.gov) with BLAST [24]. Sequences were submitted to NCBI (Accession numbers MN575689.1 
and MN575688.1). The yeast strain was identified as Pichia sp., the fungal strain M8 was identified as Pezicomycotina sp.

\section{Results and Discussion}

\subsection{Biosorption of REE by Bacteria}

Initially biosorption tests with B. subtilis and four elements (lanthanum, neodymium, dysprosium and ytterbium, each $15 \mu \mathrm{mol} / \mathrm{L}$, no parallels) showed a selective preference of $B$. subtilis for ytterbium at different amounts of biomass, and a reduction of uptake of REEs per biomass with increasing biomass (Figure S1, Table S1). Biosorption at $\mathrm{pH} 4$ and $\mathrm{pH} 5$ was also tested and resulted in more than $96 \%$ REE removal and did not show any difference concerning different amounts of biomass (data not shown). Uptake for lanthanum was 5.6, 5.5 and $5.8 \mu \mathrm{mol} / \mathrm{g}$ for two parallel assays at $\mathrm{pH} 4$ and a biomass of $2.5 \mathrm{~g} / \mathrm{L}$, these data are in accordance with a previous study with a REE/BM ratio of 2.9 with lanthanum as single metal in solution [26].

Increasing the REE concentration with increasing REE/BM ratio decreased the relative biosorption with small influence on the preference for the heavy rare earth elements (HREEs) (Figure 1).
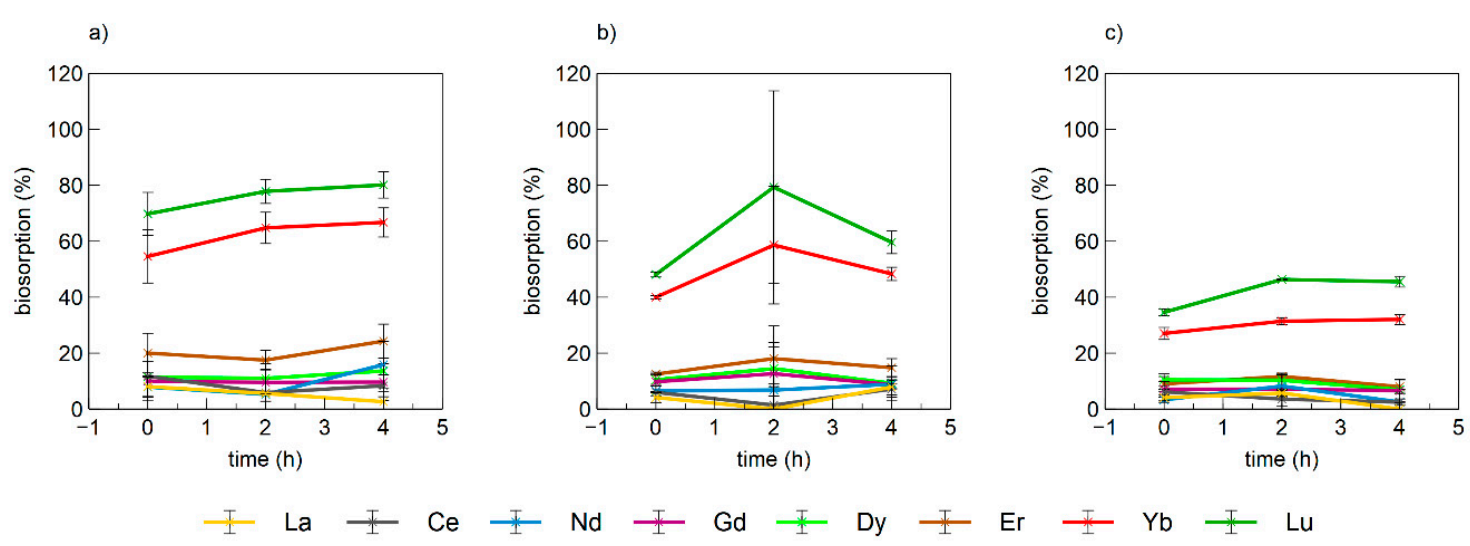

Figure 1. Biosorption of REEs by B. subtilis with increasing REE/BM ratio at $\mathrm{pH} 2.5, \mathrm{BM} 4 \mathrm{~g} / \mathrm{L}$, (a-c): REE/BM ratio 3.75, 7.5 and 15, respectively; REE concentration of each element was 15, 30 and $60 \mu \mathrm{mol} / \mathrm{L}$, respectively. Error bars show standard deviation of two parallels.

This aspect together with the result, that biosorption did not increase very much especially for ytterbium with a biomass of more than $5 \mathrm{~g} / \mathrm{L}$ (Figure S1b,d,f,h) is essential for application of biosorption technologies because producing biomass is an energy and resource consuming process. In conclusion, for comparing different microorganisms in terms of possible applications, REE/BM ratio, $\mathrm{pH}$, time and absolute REE and BM concentrations must be taken into consideration.

Therefore, to evaluate the biosorption pattern of the eight REEs in solution a biomass of $5 \mathrm{~g} / \mathrm{L}$ for the gram-positive bacterium B. subtilis as well as for the gram-negative bacteria L. methylohalidivorans and $P$. inhibens was chosen for further experiments. The preference for the HREEs with different selectivity at pH 2.5 was confirmed (Figure 2). Additionally, for B. subtilis, a slight reduction of biosorption after four hours was found (Figure S1), for L. methylohalidivorans and P. inhibens a reduction of biosorption after $20 \mathrm{~h}$ was observed (Figure S2). 

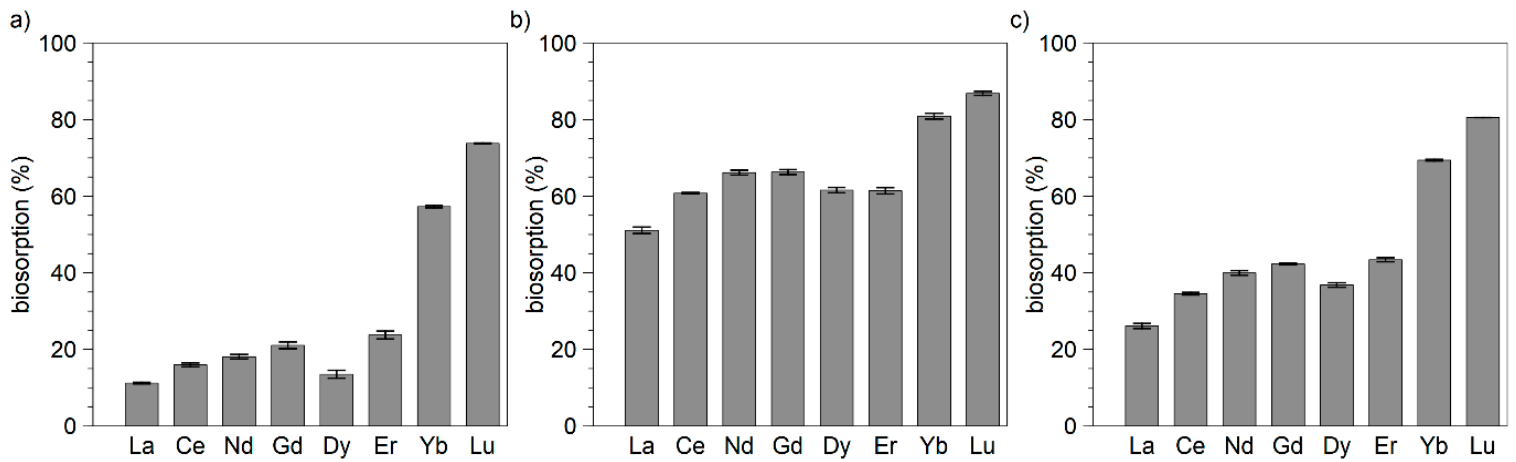

Figure 2. Biosorption of REEs by B. subtilis ((a) gram-positive), L. methylohalidivorans ((b) gram-negative) and P. inhibens ((c) gram-negative). BM $5 \mathrm{~g} / \mathrm{L}$, initial REE concentration was $15 \mu \mathrm{mol} / \mathrm{L}$ for each element, sampling took place after $2 \mathrm{~h}$. Bars show mean of two parallel assays, error bars show standard deviation.

Takahashi et al. found that heavy REE (HREE, especially $\mathrm{Tm}, \mathrm{Yb}$, and $\mathrm{Lu}$ ) are enriched on the cell surface of the gram-positive bacterium B. subtilis and the gram-negative bacterium E. coli compared to other REEs and concluded that the REE patterns suggest that there are at least two binding sites on the bacterial cell surface, i.e., carboxylate and phosphate groups [18]. Our results are in accordance with a later study of Takahashi et al. who furthermore found that HREEs form complexes with multiple phosphate sites (including phosphoester sites) with a larger coordination number $(\mathrm{CN})$ at lower REE-bacteria ratios (REE/BM) [19]. In contrast, light and middle REEs form complexes with the phosphate sites at a lower $\mathrm{CN}$. However, the fraction coordinated to carboxylate increased for all REEs with increasing REE/BM ratio, but the enrichment of HREE in the REE distribution patterns of the bacteria was less marked with an increasing REE/BM ratio [19]. Another previous study, which combined surface complexation modelling of macroscopic adsorption data with X-ray spectroscopic measurements to identify lanthanide sorption sites on the bacterial surface by the gram-negative Pantoea agglomerans suggested that there may be variations in the dominant sorption sites across the lanthanide series. The adsorption of both LREEs used (La and $\mathrm{Nd}$ ) was best modelled assuming adsorption to phosphate sites, whereas $\mathrm{Gd}, \mathrm{Er}$ and $\mathrm{Yb}$ could be modelled equally well with carboxyl or phosphate sites; samarium was better modelled with carboxyl relative to phosphate sites. However, one restriction of this study was that the observed differences in modelling were small [14] and it has to be mentioned, that the used REE/BM ratio was high, this could also contribute to a higher impact of the carboxyl sites. In contrast, concerning the europium/B. subtilis system it was found that carboxyl, phosphate, and hydroxyl (and/or amine) groups were present at the bacterial surface of B. subtilis [20]. At $\mathrm{pH} 5$, the adsorption data could be well described by mainly carboxyl groups and with increasing $\mathrm{pH}$, an increasingly deprotonated phosphate environment should be considered [20]. Concerning the data of the literature provided by Takashi et al. $[18,19]$ the REE/BM ratios are similar to the here presented data.

Considering the obvious difference between gram-positive and gram-negative bacteria in cell wall structures, it was shown, that powder of a wild type vs. a lipoteichonic acid defective strain of B. subtilis showed a better biosorption performance, indicating that lipoteichonic acids contribute to the absorption of REEs and followed the order of effectiveness La $<$ EU $<$ TM [27].

Regarding the relevant chemical groups for lanthanide binding, Gadd et al. stated that peptidoglycan carboxyl sites are the main binding sites for metal cations in the gram-positive bacterial cell and that phosphate groups contribute significantly to biosorption in gram-negative species. Furthermore, other bacterial metal-binding components are proteinaceous S-layers, and sheaths largely composed of polymeric materials with proteins and polysaccharides [3]. Interestingly, a genetically engineered gram-negative bacterium Caulobacter crescentus with a high-density cell surface display of lanthanide binding tags (composed of small proteins on its S-layer) exhibited a preference for HREEs [28]. Considering literature results 
and the observed higher selectivity for ytterbium and lutetium of the gram-positive bacterium $B$. subtilis than of the tested gram-negative bacteria (at the same REE/BM ratio), the question remains open what kind of binding mainly contributes to the biosorption of REEs at acidic $\mathrm{pH}$. A relative higher amount of phosphate groups contributing to binding of HREEs in gram-positive bacteria or a better accessibility and amount of carboxyl groups in the proteinaceous S-layer in gram-negative bacteria at low REE/BM ratios could explain the observed difference. This assumption together with results from Takahashi et al. [18] that HREEs form complexes with multiple phosphate sites (including phosphoester sites) with a larger coordination number at lower REE/BM ratios would also explain the diminishing relative difference between the absorption of LREEs and HREEs with increasing biomass ( $2.5 \mathrm{~g} / \mathrm{L} \mathrm{vs.} 5 \mathrm{~g} / \mathrm{L})$ and decreasing REE/BM ratio $(6 \mu \mathrm{mol} / \mathrm{g}$ vs. $3 \mu \mathrm{mol} / \mathrm{g})$. This also supports the results from Takahashi et al. [19] that, at low REE/BM ratios, HREEs are bound to phosphate sites with a higher coordination number (Figure 3).

a)

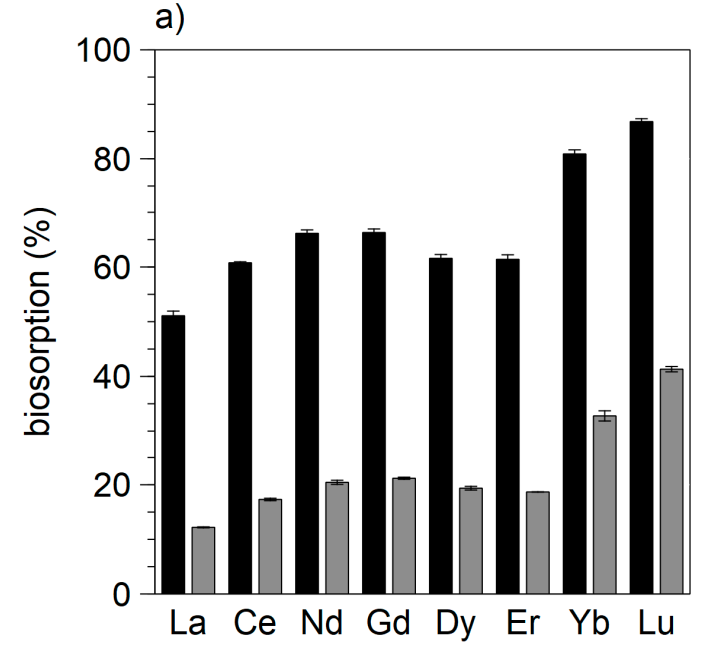

b)

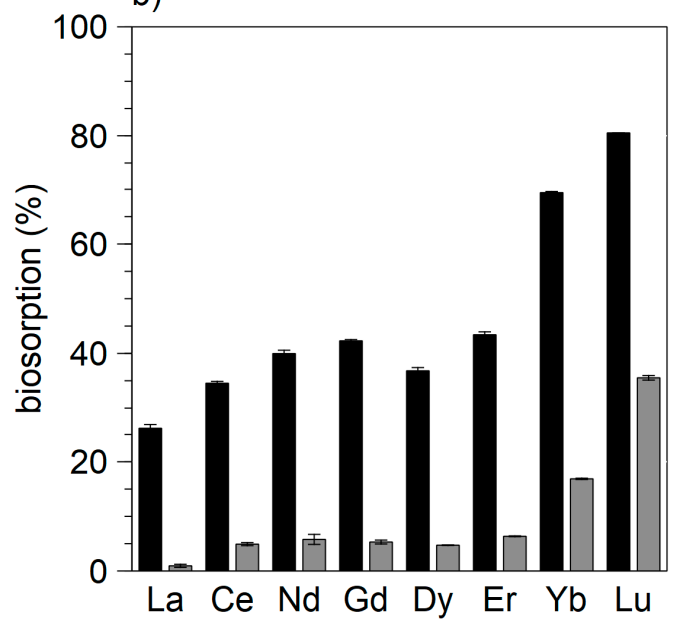

Figure 3. Biosorption of REEs by L. methylohalidivorans (a) and P. inhibens (b). BM $2.5 \mathrm{~g} / \mathrm{L}$ (grey) and $5 \mathrm{~g} / \mathrm{L}$ (black), initial REE concentration was $15 \mu \mathrm{mol} / \mathrm{L}$ for each element, sampling took place after $2 \mathrm{~h}$. Bars show mean of two parallel assays, error bars show standard deviation.

Competition of metal cations for metal binding tags has been described in some studies [29]. For example, it has been shown that cations like $\mathrm{Al}^{3+}$ are strong inhibitors for biosorption of REEs by Pseudomonas aeruginosa. In the same study, lanthanum biosorption was strongly affected by the presence of europium and ytterbium, whereas the extent of removal of ytterbium did not decrease to the same extent than with the addition of lanthanum ions [11]. Comparison of the results of pretests with four elements (La, Nd, Dy, $\mathrm{Yb}$ ) with those experiments with eight REEs (biomass $5 \mathrm{~g} / \mathrm{L}, \mathrm{pH} 2.5$, REEs $15 \mu$ mol each) confirmed this observation (Table S1). To investigate the question, whether at acidic $\mathrm{pH}$ other cations like $\mathrm{Fe}(\mathrm{II})$ and $\mathrm{Zr}(\mathrm{IV})$ compete with the REEs for biosorption binding sites, the relative biosorption of the eight REEs in presence of iron $\left(\mathrm{FeCl}_{2}\right)$ and zirconium $\left(\mathrm{ZrOCl}_{2}\right)$ was tested, however, although biosorption and uptake of zirconium was high, competition was not found. The mean decrease of biosorption of all eight REEs after two hours was only $0.5 \%$ compared to the experiment without zirconium and iron (Figure 4). These data are in accordance with a previous study which pointed out that Tm was selectively removed by B. subtilis powders in the presence of Fe(II) [27]. 

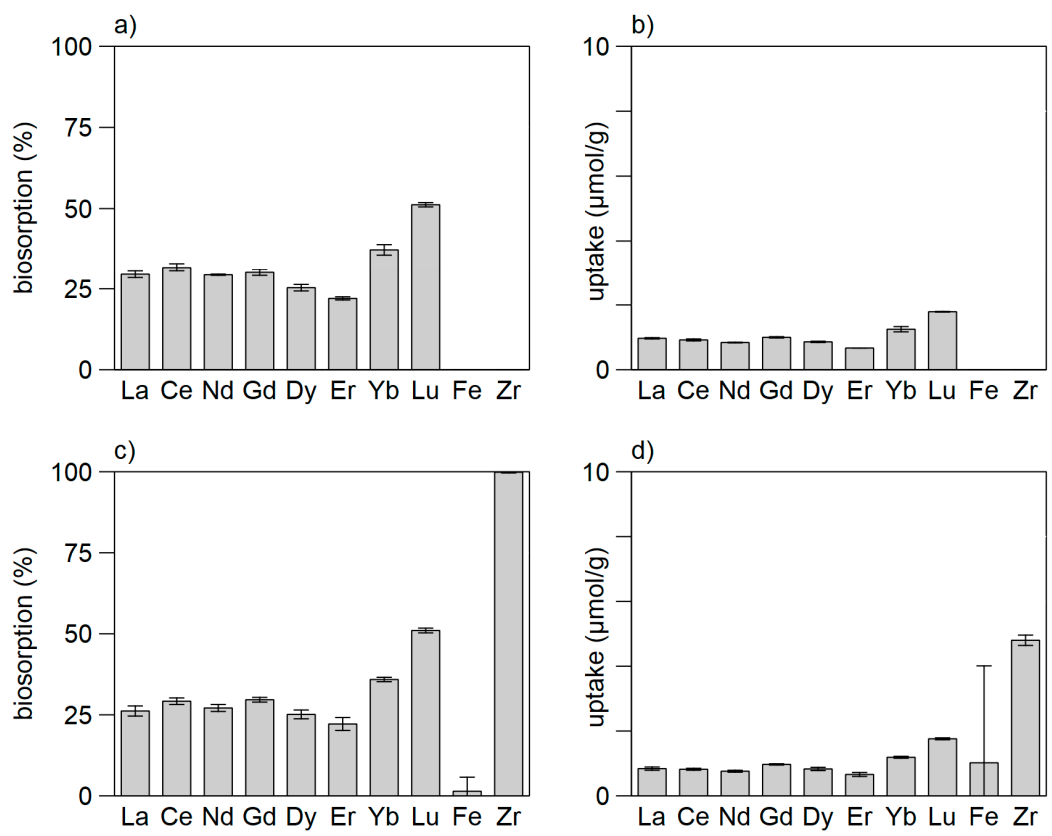

Figure 4. REE biosorption (a,c) and uptake $(\mathbf{b}, \mathbf{d})$ by B. subtilis in absence $(\mathbf{a}, \mathbf{b})$ and presence $(\mathbf{c}, \mathbf{d})$ of iron and zirconium (Fe(II): $264 \mu \mathrm{mol} / \mathrm{L}, \mathrm{Zr}(\mathrm{IV}) 16 \mu \mathrm{mol} / \mathrm{L}, \mathrm{BM} \mathrm{5g} / \mathrm{L}, \mathrm{pH} 2.5)$. Bars show mean of two parallel assays, error bars show standard deviation.

In conclusion, at low $\mathrm{pH}$, for selective removal of HREEs, biosorption by B. subtilis is a promising approach; for removal of all REEs, the marine bacterium L. methylohalidivorans seems suitable.

\subsection{Biosorption of REE by Eukaryotes}

Concerning the eukaryotes, several fungi and two algae were tested at low pH. Results are summarized in Table 2.

Table 2. Overview about biosorption capabilities of eukaryotes.

\begin{tabular}{|c|c|}
\hline Organism & Result \\
\hline Saccharomyces cerevisiae & $\begin{array}{c}\text { Tested with } \mathrm{BM} \text { of } 5,10 \text { and } 20 \mathrm{~g} / \mathrm{L} \text {, at a } \mathrm{BM} \text { of } 5 \mathrm{~g} / \mathrm{L} \\
\text { biosorption was }<50 \% \text {, biosorption was } 100 \% \text { at a } \mathrm{BM} \\
\text { of } 10 \mathrm{~g} / \mathrm{L} \text {, preference for } \mathrm{Gd}, \mathrm{Dy}, \mathrm{Yb}, \mathrm{Lu}\end{array}$ \\
\hline Pichia naganishii [MB\#320511] & $\begin{array}{l}\text { Tested for } \mathrm{La}, \mathrm{Nd}, \mathrm{Dy}, \mathrm{Yb} \text { at a } \mathrm{BM} \text { of } 2.5,5 \text { and } 10 \mathrm{~g} / \mathrm{L} \text {. } \\
\text { At a } \mathrm{BM}>5 \mathrm{~g} / \mathrm{L} \text {, biosorption }>80 \% \text {. }\end{array}$ \\
\hline Pichia sp. & Preference for $\mathrm{Ce}, \mathrm{Nd}, \mathrm{Gd}, \mathrm{Dy}$ \\
\hline $\begin{array}{l}\text { Catenulostroma chromoblastomyces } \\
\text { CBS } 597.97\end{array}$ & $\begin{array}{l}\text { Preference for Ce, Nd, Gd, Dy, at a BM of } 7.5 \mathrm{~g} / \mathrm{L} \\
\sim 30 \% \text { biosorption }\end{array}$ \\
\hline Pezicomycotina sp. & $\begin{array}{c}\text { Tested with } \mathrm{BM} \text { of } 2,5 \text { and } 10 \mathrm{~g} / \mathrm{L} \text {, biosorption }<20 \% \text {, } \\
\text { preference for } \mathrm{Gd}, \mathrm{Yb}, \mathrm{Lu}\end{array}$ \\
\hline Fusarium sp. & $\begin{array}{c}\text { Preference for Nd, Gd, Gy, Lu, tested for } 4 \text { elements } \\
\text { (La, Nd, Dy, Yb), BM } 4 \text { g/L } \sim 40 \% \text {, BM } 5 \mathrm{~g} / \mathrm{L} \\
\text { biosorption } \sim 100 \%\end{array}$ \\
\hline Messastrum gracilis & Literature data not confirmed [12] \\
\hline Galdieria sulphuraria & Literature data not confirmed [15] \\
\hline
\end{tabular}

Concerning biosorption capacities of fungi, a preference for the MREEs (middle rare elements), partly together with a preference for ytterbium and lutetium was observed (Table 2). Interestingly, strain Pezicomycotina sp. which was isolated from an abandoned acid copper mine (Marsberg, Germany) showed the lowest biosorption ( $<20 \%$ at a BM of $10 \mathrm{~g} / \mathrm{L})$. This might be due to adaptation 
to the metal-rich environment inhibiting absorption of cations to the cell wall. Because the Pichia sp. strain was most promising for biosorption at low $\mathrm{pH}$, the total biosorption at different $\mathrm{pH}$ values with two different amounts of biomass ( 2 and $4 \mathrm{~g} / \mathrm{L}$ ) was tested in order to estimate a suitable biomass for further work. Biosorption increased still after four hours, therefore it was tested up to $24 \mathrm{~h}$. In a pretest, a compensation of $\mathrm{pH}$ effect on biosorption with increasing biomass but a decreasing biosorption per g/dry weight was observed (Figure S3). To discriminate a possible preference for elements, $2 \mathrm{~g} / \mathrm{L} \mathrm{BM}$ was chosen for further tests. Pretests with $1.5 \%$ agarose and $2 \%$ agarose as immobilization matrix carried out with B. subtilis showed a better biosorption with $1.5 \%$ agarose (Figure S4), therefore a recovery experiment with immobilized Pichia sp. in 1.5\% agarose was conducted. The preference of certain REEs, specifically cerium, neodymium, gadolinium and dysprosium was confirmed by the data (Figure 5). For application, the metals could be recovered from the ashes.
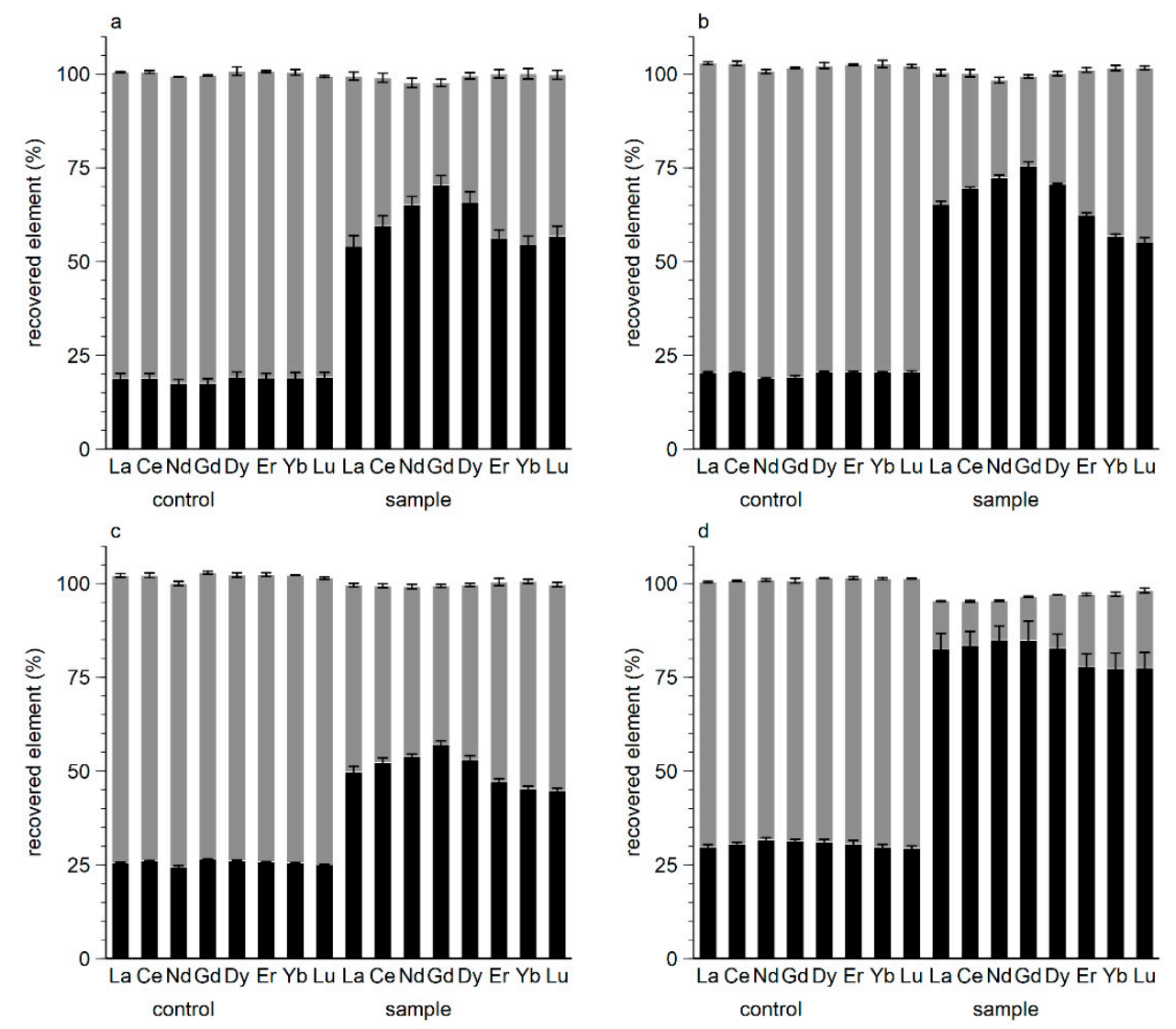

Figure 5. Recovery experiment: biosorption of Pichia sp. immobilized in agarose, biomass $2 \mathrm{~g} / \mathrm{L}, \mathrm{pH} 2.5$, samples were taken after $24 \mathrm{~h}$. Bars show mean of two parallel assays, error bars show standard deviation, (a-d) $\mathrm{pH} 1.5,2.5,3.5$ and 4.5, respectively.

The reason for the reduction of biosorption at $\mathrm{pH} 3.5$ remained open, due to the fact, that the biomass was diluted after centrifugation, experimental bias (e.g., clumping of biomass) cannot be completely excluded. Nevertheless, preference for the middle rare elements was confirmed.

To test the REE biosorption capability under application related conditions wastewater from a sewage plant was used. Concerning the middle rare elements, the annual emission of gadolinium (used as contrast agent) by medical hospitals and ambulances was estimated to be $1160 \mathrm{~kg}$ in Germany for 1996/1997, resulting in an average gadolinium concentration in surface water of $0.026 \mu \mathrm{g} / \mathrm{L}$ [30]. Gadolinium load resulting from magnetic resonance imaging is well investigated in Germany and Switzerland [31-33]. Recently, the first evidence that anthropogenic gadolinium enters human food chain was found [34]. Therefore, to elucidate whether biosorption is applicable here, an experiment with two samples ( $\mathrm{pH}$ 8.1) from pre- and post-clarification wastewater from a sewage treatment plant 
in Germany was carried out. The amount of REEs was determined with ICP-MS. The gadolinium concentration was 3.8 and $3.9 \mathrm{nmol} / \mathrm{L}$ for the two water samples, respectively $(0.6 \mu \mathrm{g} / \mathrm{L})$. The amount of all other REEs together was below $0.6 \mathrm{nmol}$. For experiments, two approaches were selected: first, the samples were used without any modification, second, the samples were acidified to $\mathrm{pH} 2.5$. Additionally, it was tested whether filtration $(0.2 \mu \mathrm{m})$ of the samples had an influence.

The results did not show any biosorption using the not acidified samples. It is known that rare earth ions form complexes with hydroxide or carbonate at $\mathrm{pH}$ higher than approximately 5.5 [35]. Biosorption of the acidified samples was strongly depended on the REE/BM ratio, increasing the biomass resulted in biosorption of $\sim 75 \%$ for both (pre- and post-clarification) samples. Post-clarification samples exhibited a better biosorption, this might be due to the lack of competing cations or complexing organic molecules. At the higher REE/BM ratio, a better biosorption within the unfiltered samples was found (Figure 6a,c). In conclusion, Pichia sp. seems suitable to recover gadolinium from wastewater at appropriate conditions.
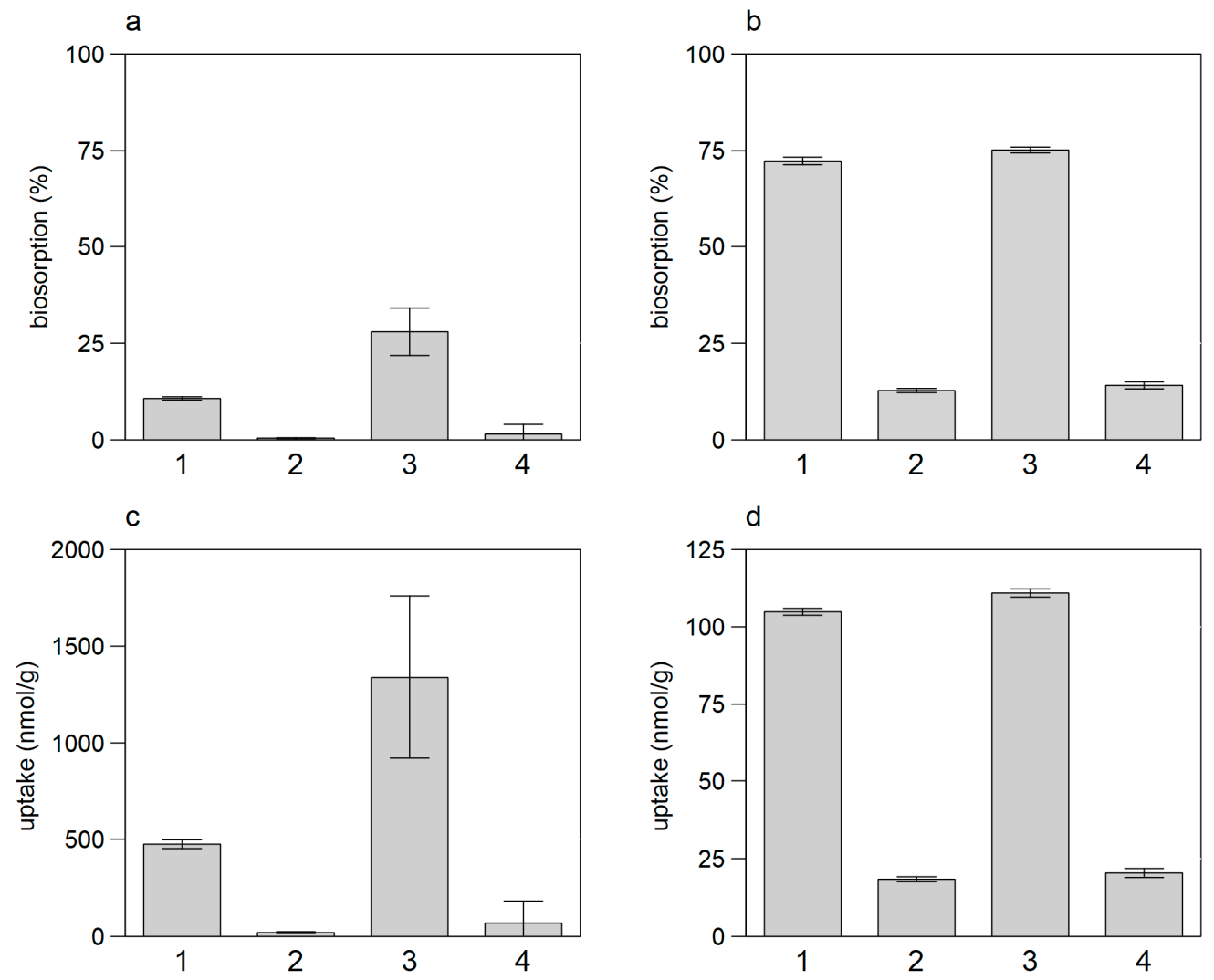

Figure 6. Biosorption and amount of uptake of gadolinium by Pichia sp. from acidified wastewater. (a,c) REE BM/ratio: $3.9 \mu \mathrm{mol} / \mathrm{g}$; (b,d) REE/BM ratio: $0.13 \mu \mathrm{mol} / \mathrm{g}$; samples 1, 3: post clarification wastewater; samples 2, 4: pre clarification wastewater; samples 1, 2: $0.2 \mu \mathrm{m}$ filtered; samples 3, 4: not filtered. Error bars show standard deviation of two parallels.

Concerning Fusarium sp., Catenulostroma chromoblastomyces and Pichia sp., in various pH tests, decreased biosorption at a $\mathrm{pH}$ of 2.5 or 3.5, respectively, was seen (Figure 5, Figure S5, for Fusarium sp. not shown).

Because fungal cell walls are complex macromolecular structures predominantly consisting of chitins, glucans, mannans and proteins, but also containing other polysaccharides, lipids and pigments, e.g., melanin [3], it is conceivable, that at low $\mathrm{pH}$ the lanthanide binding tags of the eukaryotic cell wall integrity are destroyed. Complex interactions of protons with for example chitin [36] may mask lanthanide binding tags. The observed increasing biosorption at pH below 2.5-3.5 could also be explained by absorption on released intracellular matter (e.g., proteins or walls of cell organelles). 
On the other hand, for the green algae Galderia sulphuraria, an active incorporation of REEs into the cell at $\mathrm{pH} 1.0-1.5$ was suggested [15]. Further research to clarify this observed phenomenon is needed.

In addition to fungi, REE biosorption was tested for the red algae G. sulphuraria and the green algae M. gracilis for different cultivation conditions as described in the literature [12,15]. However, significant biosorption capabilities were not detected for both algae.

\subsection{Tests with Dead vs. Living Biomass}

The use of dead biomass instead of to living biomass has several advantages: storage of biomass is easier, versatility is better, the degree of uptake is higher, it might be possible to reuse the biomass, recovery with toxic substances is possible [29]. We tested this for Bacillus subtilis and one fungus (Fusarium sp.) with increasing REE concentrations and better results were achieved with living biomass vs. dead biomass (Figure 7).
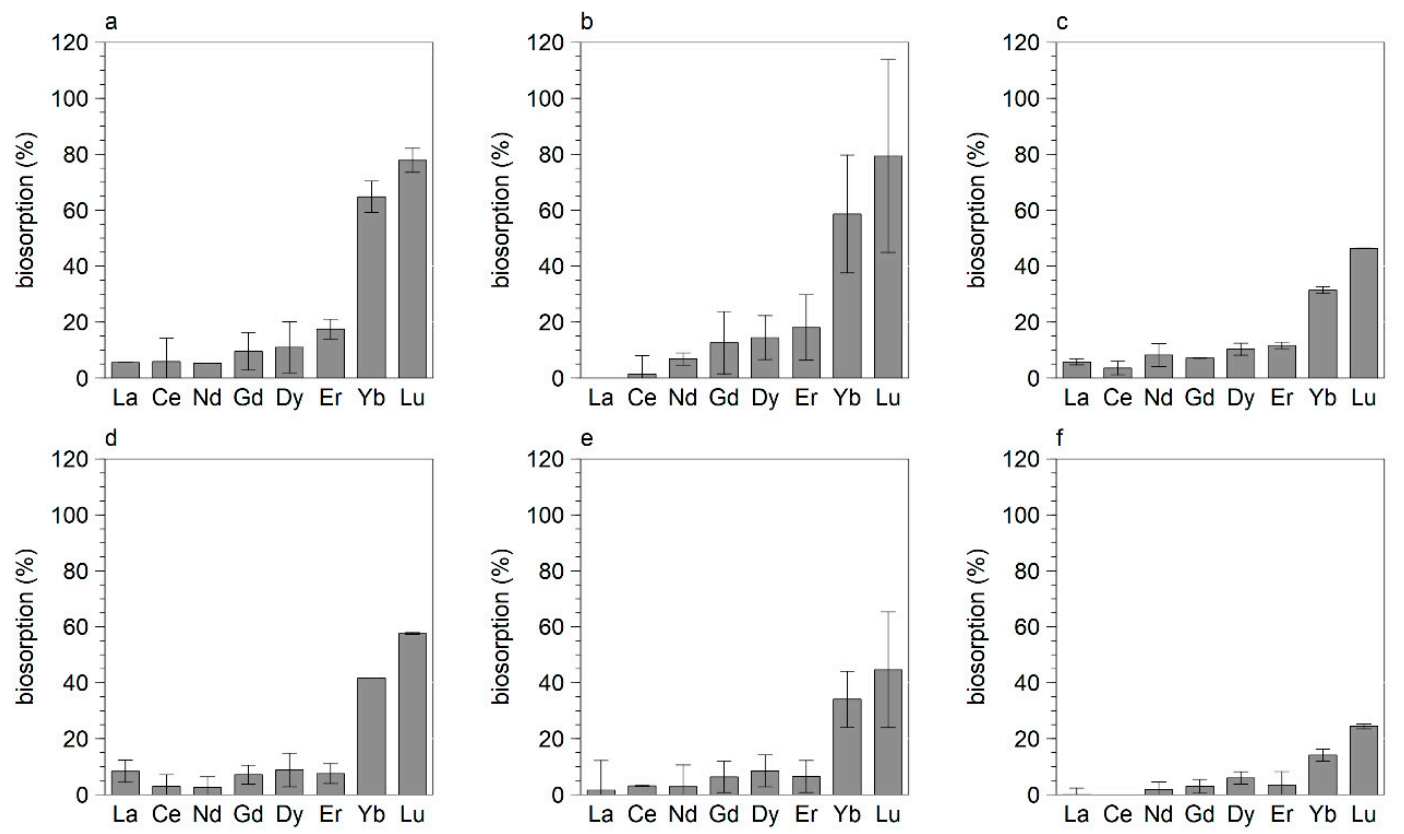

Figure 7. Comparison of REE biosorption by B. subtilis with living $(\mathbf{a}-\mathbf{c})$ and dead $(\mathbf{d}-\mathbf{f})$ biomass, (a,d): concentration of REEs each $15 \mu \mathrm{mol} / \mathrm{L},(\mathbf{b}, \mathbf{e})$ : concentration of REEs each $30 \mu \mathrm{mol} / \mathrm{L},(\mathbf{c}, \mathbf{f})$ : concentration of REEs each $60 \mu \mathrm{mol} / \mathrm{L}, \mathrm{BM} 4 \mathrm{~g} / \mathrm{L}, \mathrm{pH} 2.5$.

Higher biosorption with living biomass was also achieved with Fusarium sp. (Figure 8).
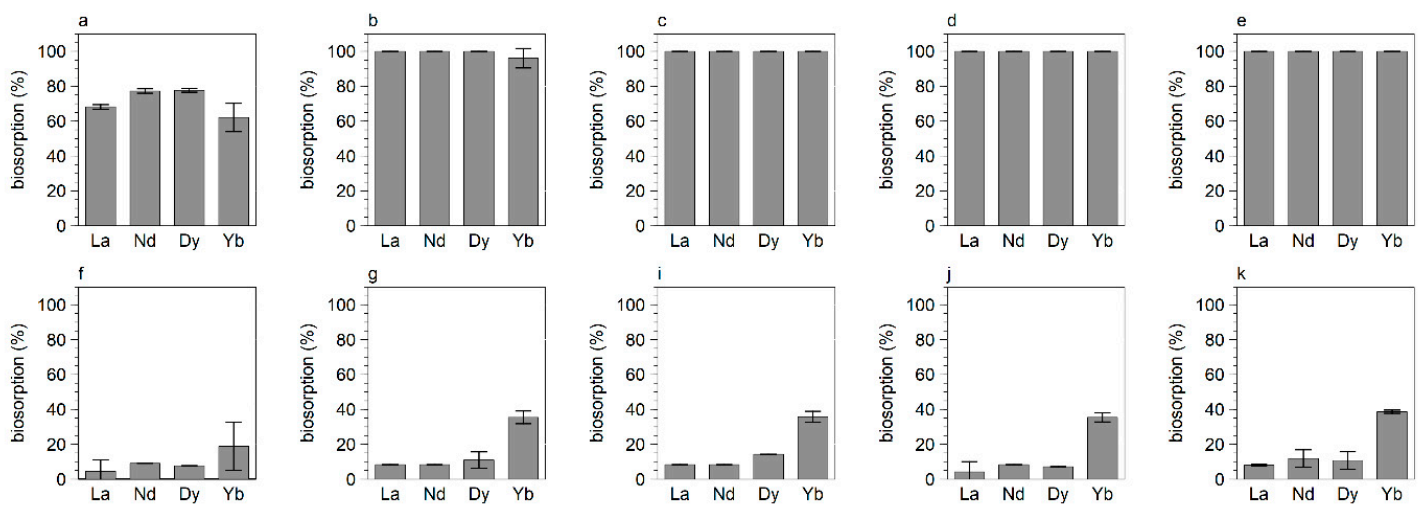

Figure 8. Comparison of REE biosorption by Fusarium sp. with living (a-e) and dead (f-k) biomass at different time intervals, (a,f): 0 h, (b,g): 2.5 h, (c,i): 5.5 h, (d, j): 8 h, (e,k): 25 h. Biomass was $5 \mathrm{~g} / \mathrm{L}$, $\mathrm{pH}$ was 2.5 . 
These results are in accordance with those of the red algae Galderia sulphuraria which also performed better biosorption with living vs. dead BM [15].

\section{Conclusions}

At low $\mathrm{pH}$, a careful selection of microbial species for biosorption of REE is necessary. The importance of the REE/BM ratio for application strategies was shown. Biosorption preferences were shown for different REEs at comparable application conditions ( $\mathrm{pH}, \mathrm{REE} / \mathrm{BM}$ ratio). Competing effects were found for $B$. subtilis for interaction of eight REEs but not for the addition of zirconium to the eight REEs at acidic $\mathrm{pH}$. These results confirm and complement previous investigations with three elements [11]. For the chosen approach (to elucidate biosorption capabilities of microorganisms without further genetic or chemical modifications at low $\mathrm{pH}$ ), the better biosorption results with live versus dead biomass confirmed the importance of cell integrity for biosorption. Due to discrimination between HREEs and LREEs, the gram-positive B. subtilis seems suitable for biosorption of HREEs. Due to the lower need of biomass to achieve a relevant biosorption of all REEs, eukaryotes-especially fungi and yeasts such as Pichia sp.- - should be given priority. Nevertheless, gram-negative marine bacteria show a high potential for biosorption of all REEs (L. methylohalidivorans) and HREEs (P. inhibens). Pichia sp. could be used successfully to recover anthropogenic gadolinium from wastewater. For successful application strategies, attention should be paid on REE/BM ratios, competition experiments and enlightenment of biosorption mechanisms based on the biochemical and physical background.

Supplementary Materials: The following are available online at http://www.mdpi.com/2075-4701/10/7/954/s1, Table S1: Comparison of the relative biosorption of four REEs by B. subtilis with the relative biosorption of eight REEs by B. subtilis at $\mathrm{pH}$ 2.5. Figure S1: Relative biosorption and amount of REE uptake by B. subtilis. Figure S2: Relative biosorption by L. methylohalidivorans and P. inhibens at different amounts of biomass. Figure S3: REE biosorption by Pichia sp. at two different amounts of biomass. Figure S4: Relative biosorption by B. subtilis immobilized in 1.5\% and 2\% agarose. Figure S5: Relative biosorption by C. chromoblastomyces.

Author Contributions: Conceptualization: A.B. and A.S.; Data curation: A.B.; Formal Analysis: A.B.; Investigation: A.B. and S.F.R; Supervision: A.S.; Validation: A.B.; Visualization: A.B.; Writing-original draft: A.B.; Writing-review \& editing: A.B., S.F.R. and A.S. All authors have read and agreed to the published version of the manuscript.

Funding: This research was part of the $\mathrm{r} 4$ project SEEsand funded by the German Bundesministerium für Bildung und Forschung (BMBF), grant number FKZ 033R163B.

Acknowledgments: We thank Martine Berger from ICBM Oldenburg (Institut für Chemie und Biologie des Meeres) for providing biomass of L. methylohalidivorans and P. inhibens and Ruiyong Zhang (BGR) for providing the strain Pezicomycotina sp. We also thank Claudia Rathmann for delivery of wastewater samples. Many thanks for straightforward help with lab work to Gudrun Mengel-Jung (BGR).

Conflicts of Interest: The authors declare no conflict of interest.

\section{References}

1. Tsezos, M. Biosorption: A mechanistic approach. Adv. Biochem. Eng. Biotechnol. 2014, 141, $173-209$. [CrossRef]

2. Fomina, M.; Gadd, G.M. Biosorption: Current perspectives on concept, definition and application. Bioresour. Technol. 2014, 160, 3-14. [CrossRef] [PubMed]

3. Gadd, G.M. Biosorption: Critical review of scientific rationale, environmental importance and significance for pollution treatment. J. Chem. Technol. Biotechnol. 2008, 84, 13-28. [CrossRef]

4. Michalak, I.; Chojnacka, K.; Witek-Krowiak, A. State of the art for the biosorption process-a review. Appl. Biochem. Biotechnol. 2013, 170, 1389-1416. [CrossRef] [PubMed]

5. Ilyas, S.; Lee, J.-C. Biometallurgical recovery of metals from waste electrical and electronic equipment: A review. ChemBioEng Rev. 2014, 1, 148-169. [CrossRef]

6. Andrès, Y.; Gérente, C. Removal of rare earth elements and precious metal species by biosorption. In Microbial Biosorption of Metals; Kotrba, P., Mackova, M., Macek, T., Eds.; Springer: Dordrecht, The Netherlands, 2011; pp. 179-196. ISBN 978-94-007-0443-5. 
7. Akcil, A. Critical and Rare Earth Elements. Recovery from Secondary Resources; CRC Press, Taylor et Francis Group: Boca Raton, FL, USA; London, UK; New York, NY, USA, 2020; ISBN 9780367086473.

8. Andrès, Y.; MacCordick, H.J.; Hubert, J.-C. Adsorption of several actinide (Th, U) and lanthanide (La, Eu, $\mathrm{Yb}$ ) ions by Mycobacterium smegmatis. Appl. Microbiol. Biotechnol. 1993, 39. [CrossRef]

9. Karavaiko, G.I.; Kareva, A.S.; Avakian, Z.A.; Zakharova, V.I.; Korenevsky, A.A. Biosorption of scandium and yttrium from solutions. Biotechnol. Lett. 1996, 18, 1291-1296. [CrossRef]

10. Texier, A.C.; Andrès, Y.; Cloirec, P.L. Selective Biosorption of Lanthanide (La, Eu) Ions by Mycobacterium smegmatis. Environ. Technol. 1997, 18, 835-841. [CrossRef]

11. Texier, A.-C.; Andrès, Y.; Le Cloirec, P. Selective biosorption of lanthanide (La, Eu, Yb) ions by Pseudomonas aeruginosa. Environ. Sci. Technol. 1999, 33, 489-495. [CrossRef]

12. Palmieri, M.C.; Garcia, O.; Melnikov, P. Neodymium biosorption from acidic solutions in batch system. Process Biochem. 2000, 36, 441-444. [CrossRef]

13. Haferburg, G.; Merten, D.; Büchel, G.; Kothe, E. Biosorption of metal and salt tolerant microbial isolates from a former uranium mining area. Their impact on changes in rare earth element patterns in acid mine drainage. J. Basic Microbiol. 2007, 47, 474-484. [CrossRef] [PubMed]

14. Ngwenya, B.T.; Mosselmans, J.F.W.; Magennis, M.; Atkinson, K.D.; Tourney, J.; Olive, V.; Ellam, R.M. Macroscopic and spectroscopic analysis of lanthanide adsorption to bacterial cells. Geochim. Cosmochim. Acta 2009, 73, 3134-3147. [CrossRef]

15. Minoda, A.; Sawada, H.; Suzuki, S.; Miyashita, S.-I.; Inagaki, K.; Yamamoto, T.; Tsuzuki, M. Recovery of rare earth elements from the sulfothermophilic red alga Galdieria sulphuraria using aqueous acid. Appl. Microbiol. Biotechnol. 2015, 99, 1513-1519. [CrossRef] [PubMed]

16. Horiike, T.; Yamashita, M. A new fungal isolate, Penidiella sp. strain T9, accumulates the rare earth element dysprosium. Appl. Environ. Microbiol. 2015, 81, 3062-3068. [CrossRef]

17. Bonificio, W.D.; Clarke, D.R. Rare-earth separation using bacteria. Environ. Sci. Technol. Lett. 2016, 3, $180-184$. [CrossRef]

18. Takahashi, Y.; Châtellier, X.; Hattori, K.H.; Kato, K.; Fortin, D. Adsorption of rare earth elements onto bacterial cell walls and its implication for REE sorption onto natural microbial mats. Chem. Geol. 2005, 219, 53-67. [CrossRef]

19. Takahashi, Y.; Yamamoto, M.; Yamamoto, Y.; Tanaka, K. EXAFS study on the cause of enrichment of heavy REEs on bacterial cell surfaces. Geochim. Cosmochim. Acta 2010, 74, 5443-5462. [CrossRef]

20. Markai, S.; Andrès, Y.; Montavon, G.; Grambow, B. Study of the interaction between europium (III) and Bacillus subtilis: Fixation sites, biosorption modeling and reversibility. J. Colloid Interface Sci. 2003, 262, 351-361. [CrossRef]

21. Saitoh, N.; Fujimori, R.; Nakatani, M.; Yoshihara, D.; Nomura, T.; Konishi, Y. Microbial recovery of gold from neutral and acidic solutions by the baker's yeast Saccharomyces cerevisiae. Hydrometallurgy 2018, 181, $29-34$. [CrossRef]

22. Guillard, R.R.L.; Lorenzen, C.J. Yellow-green algae with chlorophyllide C1,2. J. Phycol. 1972, 8, 10-14. [CrossRef]

23. Webster, G.; Newberry, C.J.; Fry, J.C.; Weightman, A.J. Assessment of bacterial community structure in the deep sub-seafloor biosphere by $16 \mathrm{~S}$ rDNA-based techniques: A cautionary tale. J. Microbiol. Methods 2003, 55, 155-164. [CrossRef]

24. Altschul, S.F.; Gish, W.; Miller, W.; Myers, E.W.; Lipman, D.J. Basic local alignment search tool. J. Mol. Biol. 1990, 215, 403-410. [CrossRef]

25. Hall, T.A. BioEdit: A user-friendly biological sequence alignment editor and analysis program for Windows 95/98/NT. Nucleic Acids Symp. Ser. 1999, 41, 95-98.

26. Mullen, M.D.; Wolf, D.C.; Ferris, F.G.; Beveridge, T.J.; Flemming, C.A.; Bailey, G.W. Bacterial sorption of heavy metals. Appl. Environ. Microbiol. 1989, 55, 3143-3149. [CrossRef] [PubMed]

27. Moriwaki, H.; Koide, R.; Yoshikawa, R.; Warabino, Y.; Yamamoto, H. Adsorption of rare earth ions onto the cell walls of wild-type and lipoteichoic acid-defective strains of Bacillus subtilis. Appl. Microbiol. Biotechnol. 2013, 97, 3721-3728. [CrossRef] [PubMed]

28. Park, D.M.; Reed, D.W.; Yung, M.C.; Eslamimanesh, A.; Lencka, M.M.; Anderko, A.; Fujita, Y.; Riman, R.E.; Navrotsky, A.; Jiao, Y. Bioadsorption of rare earth elements through cell surface display of lanthanide binding tags. Environ. Sci. Technol. 2016, 50, 2735-2742. [CrossRef] 
29. Vijayaraghavan, K.; Yun, Y.-S. Bacterial biosorbents and biosorption. Biotechnol. Adv. 2008, 26, $266-291$. [CrossRef]

30. Kümmerer, K.; Helmers, E. Hospital effluents as a source of gadolinium in the aquatic environment. Environ. Sci. Technol. 2000, 34, 573-577. [CrossRef]

31. Tepe, N.; Romero, M.; Bau, M. High-technology metals as emerging contaminants: Strong increase of anthropogenic gadolinium levels in tap water of Berlin, Germany, from 2009 to 2012. Appl. Geochem. 2014, 45, 191-197. [CrossRef]

32. Kulaksız, S.; Bau, M. Anthropogenic dissolved and colloid/nanoparticle-bound samarium, lanthanum and gadolinium in the Rhine River and the impending destruction of the natural rare earth element distribution in rivers. Earth Planet. Sci. Lett. 2013, 362, 43-50. [CrossRef]

33. Vriens, B.; Voegelin, A.; Hug, S.J.; Kaegi, R.; Winkel, L.H.E.; Buser, A.M.; Berg, M. Quantification of element fluxes in wastewaters: A nationwide survey in Switzerland. Environ. Sci. Technol. 2017, 51, 10943-10953. [CrossRef] [PubMed]

34. Schmidt, K.; Bau, M.; Merschel, G.; Tepe, N. Anthropogenic gadolinium in tap water and in tap water-based beverages from fast-food franchises in six major cities in Germany. Sci. Total Environ. 2019, 687, 1401-1408. [CrossRef] [PubMed]

35. Luo, Y.-R.; Byrne, R.H. Carbonate complexation of yttrium and the rare earth elements in natural waters. Geochim. Cosmochim. Acta 2004, 68, 691-699. [CrossRef]

36. Roy, J.C.; Salaün, F.; Giraud, S.; Ferri, A.; Chen, G.; Guan, J. Solubility of chitin: Solvents, solution behaviors and their related mechanisms. In Solubility of Polysaccharides; Xu, Z., Ed.; InTech: London, UK, 2017; ISBN 978-953-51-3649-1.

(C) 2020 by the authors. Licensee MDPI, Basel, Switzerland. This article is an open access article distributed under the terms and conditions of the Creative Commons Attribution (CC BY) license (http://creativecommons.org/licenses/by/4.0/). 